[14]

\title{
Rice Marketing System and Role of Middlemen in Nepal
}

\author{
-A Case Study of Chitwan District-
}

\section{Achyut Nainabasti* and $\mathrm{Hu} \mathrm{Bai}^{* * *}$}

\author{
ネパールの米流通構造および仲買人の役割 \\ —チトワン地域の事例研究—— \\ アチュート・ナイナバスティ（愛媛大学連合農学研究科） \\ 胡柏（愛媛大学農学部）
}

\begin{abstract}
ネパールの農業発展には効果的な米流通システムの 確立が必要不可欠であるが, その整備は立ち後れてい る. そのため, 農家は市場情報, 信用供与, 貯蔵輸送 条件, 価格等の面に㧧いて多くの制約に直面し, 改善 が求められている. 本研究では, チトワン地区を対象 に 200 の農家と 50 の仲買人に対して現地調查し, 米流 通システムの現状, 問題点, および仲買人の役割につ いて分析した.

米の流通に扔いて仲買人が極めて大きな役割を果た していることが本研究によって明らかになった。少規 模農家は経済力が弱く換金を急ぐため, 収穫シーズン
\end{abstract}

の直後に米を仲買人に売り渡さざるを得ず，買い吅か れる現象が頻発する. 多数の仲買人によって吊り上げ られた高い消費者米価を招く要因にもなっている. 仲 買人と比較して農業協同組合の流通マージンは低率 で, 価格決定や仲買人の過度な参入の排除等において も零細農家の手助けになっている. 農業協同組合の発 展は効果的な米流通システムの構築に結び付くと考え る. なお， $30 \%$ 以上の農家は仲買人の高利息の融資に 依存している現実を考えると, 効率的な米市場の構築 や農家のマーケテイング改善のみならず, 経済発展の ためにも公的融資制度の整備が求められる.

\section{Introduction}

Rice is the major staple food and the major source of income of Nepal. It contributes more than one-fourth of the GDP and occupies $80 \%$ of the working population and provides nearly $90 \%$ of the total calorie requirements supplied by cereals. In the past, a major portion of the rice was utilized as household consumption and also as gift to relatives and friends. The market surplus was very low, that was sold often in the Haat Bazar ${ }^{1)}$ (traditional market). The share of marketable surplus has gradually increased in recent years. Hence, the

\footnotetext{
* The United Graduate School of Agricultural Sciences, Ehime University

** Faculty of Agriculture, Ehime University
}

function and efficiency of the rice marketing system has become a more important factor in both the producers' income and the consumers' living cost. Agricultural marketing system plays a crucial role in achieving the twin objectives of providing remunerative prices to the farmers for their products and ensuring regular supplies of these products to the consumers at reasonable prices [14]. Sidhu [14] in assessing the policies pertaining to agricultural marketing and input supply found that effective marketing, not only minimized losses but also motivated the farmers to produce more in order to maximize the returns from their farm. Further, Acharya et al. [1] in assessing agricultural marketing in India found that efficient agricultural marketing helps in effective distribution of farm products and inputs at 
the minimum cost from the producers to the consumers. However, in the rural area of Nepal, institutionalized marketing systems have not yet been established [7]. The rice marketing system operated by the Ministry of Agriculture \& Co-operative is in a preliminary stage. The major share of rice marketing is dominated by the middlemen such as village traders, wholesalers and rice millers. Poor farmers have to sell their production to the middlemen immediately after harvest on their offer price due to need of money and lack of storage facilities.

This situation has seriously prevented the improvement of farmer's income and, consequently, rice farming. Due to the lack of markets information, good warehouses, transportation and credit facilities, farmers are compelled to sell their products to the middlemen almost harvest time at a low farm gate price. These middlemen later obtain high prices by floating in the markets. As a consequence, a chunk of the profit goes to the middleman rather than these original producers. Pokhrel et al. [12] reported that middlemen exploit peasants and poor uneducated farmers by means of monopoly pricing and usury. Similarly, Tewari et al. [16] mentioned that the education level of small holding farmers was found to be fairly low and they were unable to arrange credit facilities in time. Therefore, the poor marketing system has been a main factor linked with rural poverty in Nepal. The government of Nepal has been giving top priority to rice production and its appropriate marketing system. Improving the marketing system of rice is considered essential for poverty alleviation, national food security and the economic development of the country [2]. However, our rural marketing system is very poor compared with other south Asian countries. Our neighbouring country specifically India has been improved the food security and poverty situation by changing rural marketing policy $^{2)}$ in agricultural sector.

Considering the above mentioned conditions, the purpose of the research is to investigate the rice marketing system and explore the role of middlemen in the marketing of rice in Nepal through a case study in the Chitwan district. This research is mainly designed to clear the real situation of rice marketing behaviors in Nepalese agriculture by a survey at farm-level. We think this is of extremely importance both for identifying the problems and causes in Nepalese agriculture and rural society, and for finding effective policy alternatives. The specific objectives are: (a) To evaluate the existing marketing activities and problems encountered by rice farmers. (b) To investigate the rice marketing channels and distribution system. (c) To evaluate the market price, cost, and margin of middlemen.

Compared with rice farming technology, production system, adoption of modern rice varieties, rice marketing has received very little scrutiny in Nepal. One of the main reason is rice traders understandably hesitant to disclose information and they are also suspicious of outsiders' questioning about such items as marketing margins and costs which impinge on tax and government regulations. Therefore, this study will provide useful information for improving and developing the rural rice marketing system and raising the farmer's household income.

\section{An Overview of the Study Area}

\section{(1) Study Area}

The case study was conducted in the Chitwan district $^{3)}$ of Nepal, which is located in the Terai region. More than $90 \%$ of farmers are engaged in rice farming as rice is a major source of income in Chitwan [6]. Around $60 \%$ farmers are smallholders with an average farm size of 0.7 ha [4]. In a four monthly statistical bulletin [4], it was recorded that $37 \%$ of the female and $21 \%$ of the male population are illiterate. Nearly $95 \%$ of the paddy fields are single-cropped only for the rainy season and harvested in the month of Oct/Nov. More than $80 \%$ of the farmers sell surplus paddy soon after harvest to the middlemen in different marketing distribution channels such as village traders, wholesalers and rice millers. The middlemen make frequent visits to the farmer's harvest area for collecting paddy.

The Chitwan district is the transit area of two main highways, i.e. the Prithvi and Mahendra highways, passing through this district. The Bharatpur Municipality (the headquarters of the Chitwan district) is a famous 
rice marketing zone in the Terai region. Therefore, the agricultural marketing information, marketing extension service and transportation facilities are comparatively better in this area. Farmers' cooperative markets, especially village cooperative societies under the supervision of DADO Chitwan, are actively working to deal directly with the consumers and also provide credit facilities to the farmers. These factors indicate that the Chitwan district is an ideal site for agricultural marketing research.

\section{(2) Framework of the Survey}

Two kinds of data are used in this study. The first is gained from the household survey of 200 rice farmers in cropping year, 2005 in which they were interviewed directly through a structured questionnaire. The interview mainly focused on land holding size, cultivated land, paddy production, consumption, marketing cost, transportation, marketing channels, price information, etc. The farmers' educational background, employment opportunities, and the problems they encountered were also considered. The farmers with smaller landholding have been thought to be the important factors for rice production in Nepalese agriculture. Dhakal et al. [5] reported that the paddy production area is in decreasing trend. This might be attributed to the fact that land for agriculture is getting scarce. These factors highly rely upon the farmers' resources or economic conditions that consequently effects on rice marketing activities. Therefore, in this study farmers were divided into five groups according to the farm size based on their land ownership: (a) Farmers having a land holding size of $<0.5 \mathrm{ha}$, (b) $0.5 \sim 1.0 \mathrm{ha}$, (c) $1.0 \sim 1.5$ ha, (d) $1.5 \sim 2$ ha and (e) $>2.0$ ha. Fifty two households $(26 \%)$ were in the under 0.5 ha group, sixty eight households (34\%) in the $0.5 \sim 1.0$ ha group, forty one households $(20.5 \%)$ in the $1.0 \sim 1.5$ ha group, seventeen households $(8.5 \%)$ in the $1.5 \sim 2$ ha group and twenty two households (11\%) in the $>2$ ha group.

The results of the survey indicated that about $85 \%$ of the farmers reported that the selling of their product as their most important problem. The major problems reported by farmers were: (a) low price due to glut in the market during peak harvest season. (b) price dictation by buyers and (c) unstable prices. Therefore, an additional marketing survey was carried out comprising 50 middlemen, including 14 village traders, 9 wholesalers, 7 cooperatives, 8 rice millers and 12 retailers in the cropping year 2006. They were selected with the help of DADO, Chitwan, and interviewed using a structured questionnaire directly related to sales of paddy, market outlets, pricing, marketing costs and margins.

\section{(3) Rice production and surplus status of surveyed farmers}

Table 1 presents the outline of surveyed farmers, paddy outputs and disposal patterns. The average number of family members is 6 to 8 persons regardless of all farm size, which is similar to the national average of 6 persons [12]. The numbers of farmers with farm sizes of $<0.5$ ha and $0.5-1$ ha are 52 and 68 , accounting for $60 \%$ of the total surveyed farmers. Likewise more than $76-90 \%$ of the total land holding areas are occupied by paddy fields. The total output and marketable surplus ratio is significantly higher in larger farms. Marketable surplus is the part of harvest available for sale after meeting family needs, seed requirements, wages in kind and gifts to relatives and friends, etc. The share of market surplus in farms in the $>2.0$ ha and $1.5 \sim 2$ ha land category is $45.2 \%$ and $43.2 \%$ respectively, reflecting marketable differences followed by $21.3 \%, 16.7 \%$ and $13.4 \%$ for smaller farms with $1 \sim 1.5$ ha, $0.5 \sim 1$ ha and $<0.5$ ha respectively. Shares of payment in kind for land rent, labor wages and loan repayment in total paddy output are high in farmer groups with $0.5 \sim 1$ ha and $1 \sim 1.5$ ha.

From the survey result, it is apparent that about $65 \%$ of the farmers with $<0.5$ ha farm size have no sale and consequently, their income level is very low, which also implies a high level of food insufficiency in these families. However, the difference in the ratio of sale to output between large and small farmers is reduced by the much larger home consumption of small farmers, mainly due to larger grants of paddy to children and relatives, which are classified as home consumption.

Rice sales are concentrated after harvest within a short span of time because of the lack of warehouses 
Table 1. Average output and disposal of paddy by farmer

\begin{tabular}{lrrrrrr}
\hline \hline Farm size & average & $<0.5$ ha & $0.5 \sim 1$ ha & $1 \sim 1.5$ ha & $1.5 \sim 2$ ha & $>2.0$ ha \\
\hline Farmer household (no.) & 40 & 52 & 68 & 41 & 17 & 22 \\
Average family members (no.) & 7 & 6 & 6 & 7 & 7 & 8 \\
Land holding (ha) & 1.28 & 0.33 & 0.70 & 1.21 & 1.67 & 2.47 \\
Cultivated paddy area (\%) & 83.7 & 87.9 & 90.0 & 83.5 & 80.2 & 76.9 \\
Paddy production (kg/farm size) & 4,222 & 1,190 & 2,580 & 4,000 & 5,440 & 7,900 \\
Paddy production (kg/ha) & 3,950 & 4,300 & 4,400 & 3,940 & 3,890 & 3,820 \\
Payment in kind (\%) & 23.7 & 11.8 & 30.2 & 34.0 & 21.0 & 21.5 \\
Home consumption (\%) & 48.4 & 74.8 & 53.1 & 44.8 & 35.8 & 33.3 \\
Surplus (\%) & 28.0 & 13.4 & 16.7 & 21.3 & 43.2 & 45.2 \\
Farmers with no sale (no.) & 10 & 34 & 11 & 4 & 0 & 2 \\
\hline
\end{tabular}

Note: $1{ }^{\text {a. }}$ Includes production costs paid in kind such as land rent and harvesting labor wage and other payments of consumption loan repayment.

2) ${ }^{\text {b. Includes grant. }}$

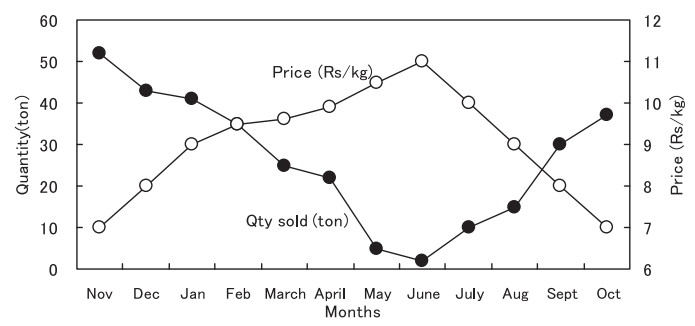

Fig. 1. Seasonal price variation and quantity sold of paddy in the study area

and other storage facilities and also due to an urgent need for cash as mentioned above. According to MOAC, Nepal [11], 66-89\% of the total marketable surplus arrived in the market during Nov-Jan. This was also observed in the study area, which resulted in drastic changes in the price of rice. Figure 1 shows that the price of paddy declines in the harvesting months and rises in the lean months. At the end of January, prices normally increase as supply diminishes. Market prices generally reach to the highest point during the off-season (May-July). To improve this situation, the Nepalese government announces the consumer's price periodically through mass media such as radio and television. But in most cases, it is not applicable in the local market due to inefficient supply, high demand, and inadequate price subsidy by the government. MOAC provide subsidy price through the national cooperative society and supports to the district level cooperatives societies to procure, store, transport and sell basic rice at reasonable price in order to minimize the food deficiency especially in the food deficit area ${ }^{4)}$. It helps to maintain reserve stocks of food grains for internal consumption and arrange warehousing facilities at the needy places in the country for the purpose of collection, storage and distribution of food grain. However, this program is only limited in remote areas. The middlemen have a significant role in the rice marketing system in the major parts of the country with their own determine prices. As a consequence the daily price is always higher than the government-set price. The low and unstable price of rice is becoming one of the main factors preventing the development of rice production by disturbing the production behavior of rice farmers.

\section{Rice distribution system and the marketing behaviour of farmers}

\section{(1) Rice distribution system}

In the study area, the rice marketed by farmers' was almost all distributed to private middlemen. Figure 2 describes the possible routes through which rice is channelled with the corresponding percentage values handled or marketed in the Chitwan district. It shows that $62.1 \%$ of the produced paddy is supplied to the wholesaler as a main marketing channel. The second major channel is village traders, accounting for $22.8 \%$. They are also called assembler wholesalers. It is common that these traders lend money in advance for farmers to guarantee supply before the harvesting 


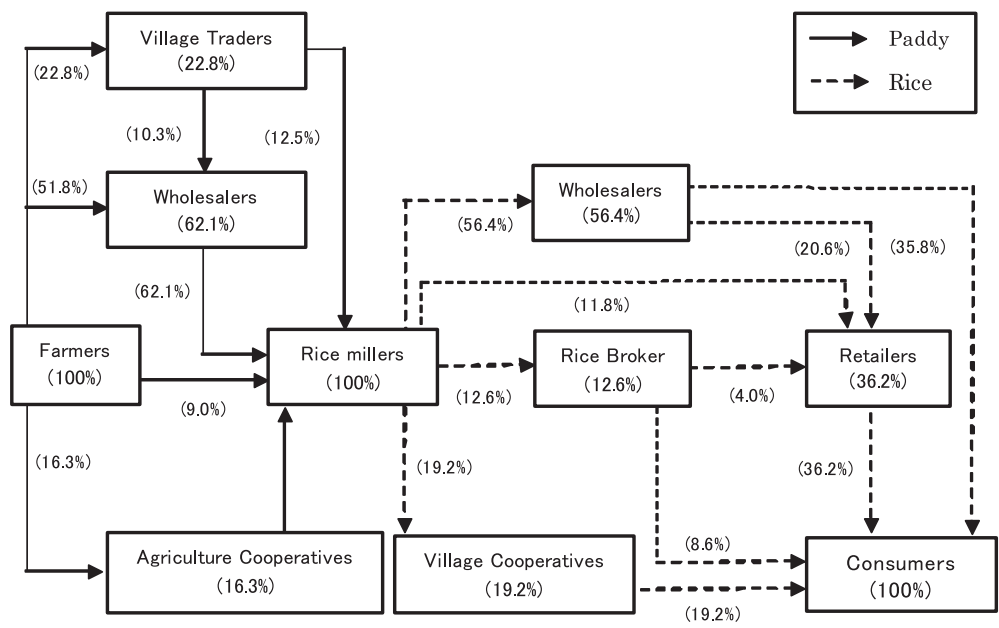

Fig. 2. Marketing distribution channel and flow of rice in the Chitwan district

Note: Black arrows indicate paddy flow and the dotted lines indicate rice flow.

season. About $16.3 \%$ of the produce is supplied through the cooperative. Small land holding farmers with small quantities of rice often sell directly to the agricultural cooperatives ${ }^{5)}$. Such farmers have less surplus and high home consumption as mentioned in table 1. Moreover, other middlemen hesitate to buy small amount of rice mainly due to their greater expenditure in transportation. But cooperative buy even a very small amount in any time as they are located in the same or neighbouring village. This is one of the major characteristics of agricultural cooperatives societies. The major support has been provided by the Ministry of Agricultural and Co-operative (MOAC) since 1980s, but in recent years government is unable to fully support to them. Therefore, some of them were to be managed by the members themselves nowadays. Village cooperatives in the study area are working under the supervision of DADO in the Chitwan district.

Rice millers are one of other key players as middlemen in rice marketing. They collect paddy from farmers, village traders, wholesalers and cooperatives and the market shares are $9 \%, 12.5 \%, 62.1 \%$ and $16.3 \%$ respectively. Rice millers are rice traders serving as an intermediary. Each miller announces the price levels of milled rice considering the milling charge and based on the prevailing prices. They supply $56.4 \%$ to wholesalers, $11.8 \%$ to retailers, $12.6 \%$ to rice brokers or commission agents, and $19.2 \%$ to farmer's cooperatives. The market share of rice brokers is uncertain because it is not a legal distribution channel and therefore, this kind of market channel is also called as rice smuggler. Sometimes, they supply rice to India, actively working near the Indian border area. Wholesalers handle a large amount (56.4\%) of rice distribution; it distributes $35.8 \%$ to the consumer and $20.6 \%$ to the retailers. Retailers obtained $20.6 \%$ from wholesalers, $11.8 \%$ from rice millers and $4 \%$ from rice brokers. They serve as the last link in the marketing channel to consumers. They buy their products practically from almost every type of middlemen and also maintain permanent shop in the market.

\section{(2) Marketing practice of paddy farmers and price determination}

Most of farmers have to sell their surplus paddy to the middlemen, as mentioned, above, all at once in bulk due to the urgent need for cash and also due to lack of storage facilities ${ }^{6)}$. Table 2 summarizes the main survey results reflecting the marketing practices of rice farmers by; (i) method of sale, (ii) mode of payment, (iii) means of transportation, (iv) types of road.

Paddy farmers dispose their products mainly through two methods of sale, pick-up and by delivery. Some farmers also used both methods, accounting for 7-23\% among different farmer sizes. Characteristically, 
Table 2. Marketing practices of paddy farmers

$(\%)$

\begin{tabular}{lccccc}
\hline \hline Farm size & $<0.5$ ha & $0.5 \sim 1$ ha & $1 \sim 1.5$ ha & $1.5 \sim 2$ ha & $>2.0$ ha \\
\hline $\begin{array}{l}\text { 1. Method of sale } \\
\text { Picked-up }\end{array}$ & 19 & 38 & 42 & 42 & 50 \\
Delivered & 58 & 51 & 51 & 41 & 36 \\
Both & 23 & 10 & 7 & 18 & 14 \\
\hline 2. Mode of payment & & & & \\
Cash & 75 & 85 & 76 & 76 & 82 \\
Credit & 25 & 15 & 24 & 24 & 18 \\
\hline 3. Means of transportation & & & \\
Tractor & 44 & 43 & 49 & 41 & 46 \\
Truck/Jeep & 0 & 3 & 17 & 41 & 41 \\
Rickshaw & 23 & 24 & 15 & 12 & 9 \\
Gada & 33 & 31 & 20 & 6 & 5 \\
\hline $\begin{array}{l}\text { 4. Type of road } \\
\text { Black top }\end{array}$ & 12 & 19 & 37 & 35 & 23 \\
Gravel & 65 & 56 & 37 & 35 & 55 \\
Rough & 23 & 25 & 27 & 29 & 23 \\
\hline
\end{tabular}

Note: 1) Gada refers to animal drawn cart.

2) Rickshaw refers to a small three-wheeled cart run by a person.

3) Some farmers reported more than one answer.

farmers with larger farm size use the pick-up method more than smaller farmers. About $50 \%$ of $>2$ ha farmers opt for picked-up rather than delivery, which implies that large scale farmers don't need to pay the cost of transportation, transport losses and other marketing costs. By contrast, $58 \%$ of $<0.5$ ha farmers deliver their surplus paddy because they need immediate cash after harvest and have no time to canvass possible buyers who could offer a better price for their products. Similarly, in case of mode of payment, cash is the most commonly reported form of payment for all farmers. Cash payment ranges from $75 \%$ to $85 \%$, immediately after sale. Remaining is partially credited depending on the volume of sale. Full payments are realized within 1-2 weeks after the products are purchased from the farmers. More than $20 \%$ of farmers report cash advance payments before harvest to facilitate the purchase of necessary inputs, hence, this practice has substantially limited the marketing opportunities of the farmers.

Similarly, market accessibility in terms of means of transport, distance from farm to market place, and destination of marketed products were also observed. The most common means of transport are tractors, rickshaw and gada. Trucks are mainly used by large holding farmers with a large quantity and long distance supply. The transportation network is very weak in Nepal. Shengman, [15] indicated that better transport infrastructure is necessary to ensure that products are delivered to distant markets in qualities and quantities that meet market demand. The results in the table offer supporting evidence for the report.

Our results show that only $12-37 \%$ farmers use black-topped roads to supply their product. Most of the roads off the main highways are either gravelled or rough (muddy). Gravelled roads are used by $35-65 \%$ farmers. About $23-29 \%$ of farmers use unpaved roads making transportation uncertain in nature. These roads can be used only when the climate is good. They are difficult to use during rain. More than $55 \%$ of farmers indicate that their farms are less than 10 kilometres away from the Narayanghat market, the most famous terminal market, apparently due to its proximity to the farms. The most favored neighbour city markets outside the district are Hetauda (east) and Butawal (west).

Table 3 summarizes the following marketing activities by farmers such as: (i) price determination, (ii) basis of price setting (iii) source of price information and (iv) source of finances. In general, the price of paddy is set by the buyers, as reported by almost all farmers. Buyers determine price for about $90 \%$ of the small farmers with <0.5 ha, $0.5-1$ ha and $1-1.5$ ha. However, $18 \%$ of farmers with $1.5-2$ ha and $14 \%$ of farmers with $>2$ ha answered that prices were determined by themselves. Large farmers also have much greater percentage ratio in using both methods. This indicates that large farmers have economic power and more knowledge in price negotiation. Similarly, more than $46-64 \%$ of farmers revealed that the prevailing market price was the main criterion used in setting prices. Negotiation between buyer and seller is also thought to be an important factor in determining price, as reported by $14-37 \%$ of farmers. Quality, size, marketing cost and profit are likely to play a much less 
Table 3. Price determination and source of finance reported by paddy farmers

\begin{tabular}{lrrrrr} 
& & & $(\%)$ \\
\hline \hline Farm size & $<0.5$ ha & $0.5 \sim 1$ ha & $1 \sim 1.5$ ha & $1.5 \sim 2$ ha & $>2.0$ ha \\
\hline i. Who determines the price & & & & & \\
Farmers & 0 & 0 & 0 & 18 & 14 \\
Buyers & 96 & 91 & 90 & 64 & 68 \\
Both & 4 & 9 & 10 & 18 & 18 \\
\hline ii. Basis of setting price & & & & & \\
Prevailing price & 60 & 63 & 46 & 59 & 64 \\
Negotiation between buyer and & 35 & 18 & 37 & 18 & 14 \\
Quality and size & 2 & 13 & 12 & 12 & 18 \\
Marketing cost+profit & 4 & 6 & 5 & 12 & 9 \\
iii. Sources of price information & & & & & \\
Buyer & 50 & 18 & 39 & 47 & 36 \\
Local market & 44 & 68 & 54 & 41 & 45 \\
Mass media & 6 & 15 & 7 & 12 & 18 \\
\hline iv. Source of finance & & & & & \\
Own & 31 & 21 & 41 & 47 & 50 \\
Bank & 21 & 29 & 29 & 35 & 32 \\
Co-operative & 15 & 19 & 22 & 6 & 18 \\
Middlemen & 33 & 31 & 17 & 12 & 0 \\
\hline & & & & & \\
\hline
\end{tabular}

important role in determining price. However some large holding farmers do place some importance on quantity and size. Survey results show that the local market centre and the buyers are the most important source of price information. In our observation, very few farmers had access to price information through mass media, such as radio or television. Some farmers are very poor and they do not have radio and television in their house. Hu \& Achyut [9] reported that the small holding farmers are almost illiterate and have poor resources. This situation resulted in low access of these resource poor farmers to market information.

Another important index is the source of finance for maintaining an assured market supply of paddy. The middlemen, especially village traders, wholesalers and rice millers, make various efforts to develop long-term trade relationships with large suppliers. Credit tying is one method used for this purpose. They advance production loans generally at the interest rate of $8 \%$ for 3 months or so, which is deducted from the proceeds of the paddy they supplied. This rate of about $2.5 \%$ per month or $35 \%$ per annum is significantly higher than that of bank lending rates of $20-25 \%$ for collateral loans, but it depends on the credit worthiness of borrowers. Farmers need loans for purchase of fertilizers, chemicals and family needs. Survey data shows that small holding farmers have limited financial resources and largely depend on middlemen. Table 4 shows that about $33 \%$ of $<0.5$ ha farmers and $31 \%$ of $0.5-1$ ha farmers take loans from middlemen. This is because local agricultural banks limit lending money finance to such small holding farmers [2]. In contrast, large holding farmers with $>2$ ha take $32 \%$ and $18 \%$ loans from commercial banks and co-operatives, respectively, and the remaining $50 \%$ depend on their own capital. This result shows that large holding farmers are economically strong compared with the small holding farmers. Due to their high economic power, storage facilities and other resources, they do not have urgent need to sell their production immediately after harvest. Further they have larger quantity of paddy to be sole to the middlemen resulting in lesser expensive for transportation to be incurred by the middlemen. Therefore, they have a power of determine 
price of their product bargaining with middlemen. It is said that they also provide loans to the small farmers with agreements of high interest rates as a landlord. Some poor farmers were forced to agree with their own traditional interest rate however we have not enough data to verify this statement.

\section{Marketing cost and margins among the different channels}

The difference between the price received by producers and that paid by consumers is called the marketing margin or price spread. The increase in the middlemen's margin necessarily results in the increase in retail prices. Similarly, an increase in marketing cost, such as wage rates or transportation costs will result in a higher retail price or lower farm gate price, or sometimes a combination of the two [17]. Since marketing margins directly influence the price at different stages of the marketing chain, the question of how the product is being efficiently marked is often important.

Table 4 shows the average farm prices and marketing margins incurred by middlemen varied by mode of sale. They are very sensitive to marketing costs because prices received for their products are derived prices [3]. As marketing costs expand, the farm price falls, and vice-versa. In this study, marketing costs are comprised of transportation cost, labor cost and packaging materials expenses. Transportation cost accounts for about $60-65 \%$, the largest portion of the total marketing costs. This result then suggests that the price of delivery is higher than the price by pick-up, apparently due to transportation cost incurred. Observation at various points of the paddy marketing channels shows that rice millers earn much more profit due to the low cost and high marketing margin. These types of middlemen often have paddy delivered by farmers and other channels rather than picking it up, so the transportation and labor costs are lower than other middlemen. They obtained $32 \%$ of the margin followed by wholesalers $27 \%$, village traders $26 \%$ and cooperatives $19 \%$. Similarly, village traders make high profits after rice millers but have less marketing margin than wholesalers. The net profit is very low for cooperatives and wholesalers which were recorded as Rs 442 and Rs 995 per ton. The important point here concerns the role of cooperative societies of Nepal as a reliable, marketable agency to the poor farmers with a reasonable margin. They are beneficial for farmers in deter-

Table 4. Marketing cost, profit and margin according to the mode of sale

\begin{tabular}{|c|c|c|c|c|c|}
\hline Middlemen & Village Traders & Wholesaler & Cooperative & Rice Millers & Retailer \\
\hline Household size & 14 & 8 & 7 & 9 & 12 \\
\hline Operating cost & 53 & 39 & 10 & 30 & 27 \\
\hline Input cost & 45 & 60 & 46 & 48 & 28 \\
\hline Transportation cost & 712 & 1,076 & 705 & 618 & 372 \\
\hline Labor cost & 334 & 469 & 398 & 329 & 261 \\
\hline Total cost & 1,144 & 1,644 & 1,159 & 1,025 & 688 \\
\hline Purchase price $^{a}$ & 7,357 & 7,094 & 6,900 & 7,160 & 7,727 \\
\hline Selling price ${ }^{\mathrm{b}}$ & 9,904 & 9,733 & 8,500 & 10,564 & 11,027 \\
\hline Total revenue (b-a) & 2,546 & 2,639 & 1,600 & 3,404 & 3,300 \\
\hline Net profit & 1,403 & 995 & 442 & 2,379 & 2,612 \\
\hline Marketing margin ${ }^{\mathrm{c}}(\%)$ & 26 & 27 & 19 & 32 & 30 \\
\hline
\end{tabular}

Note: 1) $\mathrm{c}=[(\mathrm{b}-\mathrm{a}) / \mathrm{b} * 100]$

2) Labor cost includes loading and unloading charges.

3) Transportation cost is different according to the means of transportation and distance.

4) Total revenue of village traders, wholesaler and cooperative are related paddy and rice millers and retailer are related milled rice.

5) Include price subsidy for cooperative by government.

6) Rs. is Nepali currency, rupee; $1 \mathrm{Rs}=0.65$ yen (Approx.). 
mining better prices and eliminating unnecessary involvement of middleman who eventually exploit farmers by holding products at cheaper prices. Some cooperative societies in the Chitwan district have their own storehouse (godown) and refrigerators to hold seasonal products, especially fruits and vegetables. Such farmer cooperative societies are in the transaction stage. During the survey period we have found that the Jai Kisan Farmer's Cooperative Society recently supplied their products to major cities of Nepal, including Kathmandu and Pokhera. Jonson [10] reported that agricultural co-operatives take 3 basic forms such as: i) the supply cooperatives which organizes the inputs of seeds, fertilizer and livestock. ii) the marketing cooperatives which organizes the distribution and sale of the agricultural products and iii) the product cooperatives which turns it into a higher value product ready for human (or animal) consumption. However, in Nepal the cooperative movement is still in preliminary stages focusing mainly for marketing cooperatives activities.

\section{Conclusion and policy implications}

The rice marketing system is generally dominated by the middlemen. It is mainly caused by the low level of farmer's education, under-developed infrastructure and inefficient flow of market information into rural areas. According to Eggleston et al. [8], market information and communication technology can help farmers, either by improving their bargaining position or by enabling direct sales and removal of the middlemen's market monopoly. The mark up by the middlemen is very high, leading to higher prices at the consumer level. The role of cooperative societies in rice marketing system can be a reliable marketable agency to the poor farmers with reasonable margin. Therefore, organized farmers forming a village cooperative society can be a step forward for strategizing the farmer's marketing objectives in Nepal. Similarly, managing the market through groups of organized farmers' particularly small holding farmers', can enhance their bargaining power and establish a market information system. Farmers groups can sell paddy directly to the consumers instead of selling to middlemen by arranging transportation of products by themselves. Such direct farmers' market from the producers can sell all products in the original local market which is very important in terms of segment price of both consumer and producers. Results show that large holding farmers are economically strong compared with the small holding farmers and engage in more marketing activities since they are aware of the marketing system and have better marketing conditions. More than $30 \%$ of the small holding farmers $(<1$ ha) are still dependent on the middlemen for credit facilities. It makes them much poorer and directly influences their productivity in rice production. Therefore, a public credit facility is needed for an effective competitive market and also to help improve market efficiency and the economic situation.

The major findings of this study and important policy implications are:

i. There is a need to develop and extend the systematic price information dissemination system not only at the farm and trader levels but also the consumer level. Similarly, improvements of infrastructure related to marketing facilities, particularly storage, transportation to prolong the supply of paddy and reduce marketing cost.

ii. Unnecessary proliferation of marketing channels which considerably increase marketing cost can be alleviated through formation of cooperatives. More importantly, formal farmer's organizations, such as village cooperatives, need to be strengthened. The grouping of farmers in marketing their products to the consumer directly is recommended, since the direct consumer marketing system helps to reduce costs and even small farmers can avail of better prices in the market instead of the traditional low farm price.

iii. Efficient management of market with effective laws, auction procedure, standardization of market, need to be introduced. Considering the major role played by rice mills in rice marketing in the Nepal, further investigation is required to determine their role in the marketing of rice.

iv. Government of Nepal should expend to maintain some buffer stocks of rice and intervene through 
these stocks in the markets to make available grains to consumers at reasonable prices through cooperatives.

\section{Notes}

1) Hat Bazaar is a kind of traditional market where farmers assemble goods from various parts to a fixed juncture at once or twice a week or month. They display their product to the consumers who visit the fair. The farmers are carrying their goods to the fair after the walk of two days or even a week. In spite of the development of permanent marketing channels and shops, this kind of marketing system play an important role in the rural economy.

2) See Sidhu (1986).

3) The Chitwan district represents the plain area with higher land productivity as a major rice producing area. It was identified in the Agriculture Perspective Plan (APP, 1995) as a prime agricultural region with marketing information and potential area for a national market revolution.

4) Most of the households in Nepal have annually experienced food deficit from their own production. The small farmers with lesser landholdings are the more vulnerable in meeting their food needs The CBS, 2005, reported that about 13 million people, comprising $41 \%$ of the total households, $38 \%$ in rural areas and $23 \%$ in urban areas, are regarded as food insufficient.

5) Agricultural cooperative societies or unions are formed as follows with the objectives of providing services and facilities for the economic and social development of the members according to cooperative principles. They are classifies as: (a) A primary village cooperative society comprising at least 25 members. (b) A district cooperative society with at least five societies (c) The central cooperative union with at least 25 societies (d) The national cooperative union with at least 15 unions as mentioned in clause (b), and (c) as its members. Please see "Nepal Cooperatives Act, 1992".

6) Dhital (1995) has elaborately discussed the problems and characteristics of rural Nepalese agricultural marketing. See [7].

\section{References}

[1] S.S. Acharya, "Agriculture Industry linkages: Public Policy and Some Areas of Concern", Journal of Agricultural Economics Research Review, Vol. 10 No. 2 (1997), pp. 162-175.

[2] B.B. Bahadur, "Nepal's Agriculture, Sustainability and Intervention, Looking for New Directions", Ph.D. Thesis Wageningen Agricultural University, Netherlands, 1995, pp. 1-10.
[3] R.E. Branson and D.G. Norvell, Introduction to Agricultural Marketing (McGraw-Hill, Inc., 1983), p. 139.

[4] Central Bureau of Statistics (CBS), Annual Statistical Year Book (Kathmandu, Nepal: National Planning Commission, Secretariat, 2004), pp. 30-50.

[5] D. Bishnu Prasad, T. Saitou and A. Matsuoka, "An Economic Study of Paddy Production and Fragmented Holding in Nepal", Journal of Rural Problems, Japan, Vol. 134 (1995), pp. 10-21.

[6] District Agriculture Development Office (DADO) Chitwan, Ministry of Agriculture and Cooperative, Nepal, Annual Report of 2005, (2005), pp. 1-26.

[7] Dhital Raji, "Rural Urban Agriculture Market System: Challenges and Opportunities. A Case Study, Eastern Nepal", Master Project for the Partial Fulfillment of Master Degree, Yale University, School of Forestry and Environmental Studies (USA: 2004), pp. 6-10.

[8] K. Eggleston, R. Jensen and R. Zeckhauser, "Information and Communication Techniques, Markets and Economics Development", Department of Economics, Tufts University, Working Paper, (2002), pp. 62-74.

[9] Hu Bai and Achyut Nainabasti, "Farmer Education and Productivity in Nepal Agriculture", Journal of Rural Problems, Vol. 44 No. 1 (2008), pp. 14-23.

[10] Johnston Birchall, "The International Cooperative Movement”, International Co-operative Alliance (Switzerland: Manchester University press, 1994), p. 14.

[11] MOAC, Ministry of Agriculture and Co-operatives, Nepal government, Agri-Business Promotion and Statistics Division, (2005), pp. 104-109.

[12] National Sample Census of Agriculture (NSCA), Nepal Government, National Planning Commission Secretariat, Central Bureau of Statistics, 2001/002, pp. 1-44.

[13] P. Deepak and Gopal B. Thapa, "Are Marketing Intermediaries Exploiting Mountain Farmers in Nepal? A study Based on Market Price, Marketing Margin and Income Distribution Analysis”, Science Direct, Agricultural system, (2007), pp. 151-164.

〔14] D.S. Sidhu, "Policies Pertaining to Agricultural Marketing and Input Supply", Indian Journal of Agricultural Economics, Vol. 41 (1986), pp. 310-326.

[15] Shengman Zhang, "Memorandum of the President of the International Development Association to the Executive Directors on a Country Assistance Strategy for the Kingdom of Nepal”, The World Bank: Report no. 26509-NEP, (Nov. 4, 2003), p. 11.

[16] Tewari Amrit and K. Hiraizumi, "Verification of Public Credit Programs Towards Tea Farmers in Nepal", Japanese Journal of Farm Management, Vol. 44 No. 3 (2006), pp. 1-18.

[17] G. Tomek William, Agricultural Product Prices, Fourth Edition 2003, (United States of America: 2003), pp. 117-142.

（受理日：2009 年 2 月 16 日） 